See discussions, stats, and author profiles for this publication at: https://www.researchgate.net/publication/329091180

\title{
Lifestyle mobility: shifting conception of home in modern China
}

Article $\cdot$ December 2018

DOI: 10.1504/ITA.2018.10017671

1 author:

(9) Yujie Zhu

Australian National University

22 PUBLICATIONS 217 CITATIONS

SEE PROFILE

Some of the authors of this publication are also working on these related projects:

Project Heritage View project 


\title{
Lifestyle mobility: shifting conception of home in modern China
}

\author{
Yujie Zhu \\ Centre for Heritage and Museum Studies, \\ School of Archaeology and Anthropology, \\ The Australian National University, \\ 120 McCoy Circuit, Sir Roland Wilson Building, \\ ACT 2601, Australia \\ Email: yujie.zhu@anu.edu.au
}

\begin{abstract}
This article examines new practices of mobility that are situated in-between tourism and domestic migration. The modern consumer society allows urban middle class in China to move around the country in search of alternative lifestyles and employment. Illustrating the step-by-step transformation where initial tourism leads to relocation, dwelling and new business in Lijiang, this study investigates the reasons and consequences of the relocations, and how such practices shape their cultural conception of home. Phrased here as 'lifestyle mobility', such form of movement allows people to consume an instant satisfaction of their new chosen home while using professional skills to pursue alternative entrepreneurship in the local tourism industry. This article shows how the traditional Chinese notion of home has shifted from a lineage-bounded, fixed-place unit to an individual enterprise for happiness and simultaneous connections to multiple places. However, lifestyle mobility is not only associated with individual agencies, but also closely influenced by external factors and structural conditions, such as class, ethnicity and life stages. These relocation and home-making practices are never a single act, but an on-going process of searching and strategising to meet their multiple needs at various stages of one's life.
\end{abstract}

Keywords: lifestyle mobility; home; tourism; lifestyle migration; cultural heritage; class; ethnicity; consumption; tourism anthropology; modernity; second home; hybridity; China.

Reference to this paper should be made as follows: Zhu, Y. (2018) 'Lifestyle mobility: shifting conception of home in modern China', Int. J. Tourism Anthropology, Vol. 6, No. 4, pp.357-374.

Biographical notes: Yujie Zhu is a Lecturer at the School of Archaeology and Anthropology, Australian National University. He is interested in the politics of cultural heritage, and its relation to issues like cultural tourism, urbanisation, nationalism and religious practices. He is the author of Heritage and Romantic Consumption in China (Amsterdam University Press, 2018) and a co-editor of Politics of Scale (Berghahn Books, 2018) and Sustainable Tourism Management at World Heritage Sites (UNWTO, 2006). In addition, he published more than 30 articles that appeared in leading anthropology, tourism and heritage journals, including American Anthropologist, Annals of Tourism Research, and International Journal of Heritage Studies. 


\title{
1 Introduction
}

\begin{abstract}
"The highly stressful city life forced me to move ahead. I had to work day and night. I was able to buy an apartment in Shanghai, but then did not feel happy about it. I just felt tired and wanted to have a break, a long vacation that could make me forget my work. I like Lijiang very much. The air is clean and the sky is blue. Life here is relaxed and free. You can feel something spiritual here, a healing magic. This is home."
\end{abstract}

These words came from Fei, a 31-year-old middle-class women from Shanghai, who travelled around Southwest China as a tourist and then decided to move to a popular touristic town. ${ }^{1}$ Urbanisation in China has brought about massive changes in the daily lives of urban populations. Rapid socio-spatial transformations have led to a host of social problems, such as exclusion, alienation and social segregation, and an increase in social anxiety (Hesketh and Ding, 2005). ${ }^{2}$ Consequently, middle-class Chinese are reconceptualising their sense of home and exercising greater lifestyle mobility as they search for better homes and new lifestyles. In contrast to the majority of Chinese who strives to migrate to urban areas for better social welfare, Fei escaped from urban life in search of an alternative lifestyle. She was not alone. Since 2000, a number of Han Chinese from the more economically developed eastern parts of the country moved to the countryside as an escape from their work (Xu and $\mathrm{Wu}, 2016)$. What does such relocation mean? What are the reasons behind such movement? How do such practices influence these mobile individuals' conception of home?

With these questions in mind, this research centred on Lijiang, an old town situated in southwest of China. Since UNESCO enlisted the town as World Heritage Site in 1997, Lijiang has witnessed a huge influx of visitors from everywhere in the world. Like Fei, a number of Chinese tourists visited the town for a short period with some of them deciding to settle down in Lijiang and to work in the tourism industry. Illustrating the transformation of these urban Chinese from tourists to new Lijiang residents and tourism entrepreneurs, this study investigates the reasons and consequences of such transformations. The stories of these people not only shed light on the motivations of Chinese urbanites to visit and then reside in a remote town but also on how such practices help to understand their cultural conception of home and how they use their imagination to construct it.

It can be argued that today's society is organised as networks through multiple forms of movement of people, things, images, objects, ideas and capitals (Salazar and Zhu, 2015). As such, the relation between 'home' and 'mobility' becomes essential, since it helps us understand the way we live our lives (Ralph and Staeheli, 2011). If in traditional societies, home used to be associated with fixed, bounded and enclosed places or property (Després, 1991; Somerville, 1997), in the globalised era, people require new and dynamic ways of identity expression or lifestyle improvement (Coles and Timothy, 2004). As a consequence, the traditional notion of home is challenged by a number of new meanings of home as mobile, blurred (Nowicka, 2007) and sometimes even imagined (Su, 2014). It becomes a fluid model of identification with multiple places, meanings and 'hybrid identities' that reflects people's sense of selfless and belonging (Brubaker and Cooper, 2000; Yau, 2007; King and Ari Gamage, 1994).

Based on the case study of recent tourism development in Lijiang, China, ${ }^{3}$ this paper argues that such practices of relocation are situated in-between tourism and migration. Instead of creating a new typology, I echo Cohen et al.'s (2013) notion of 'lifestyle 
mobility' to describe such phenomena that reflects the multi-functional and fluid nature of these movements. I argue that the movements are closely associated with an on-going process of home-making and a lifestyle project within contemporary consumer society. Their tourism experience, associated with the emergence in present day Chinese society of individualism and the pursuit of happiness and self-actualisation, shape their identities that in turn influence the way they develop new senses of home along their life journey. This particular form of lifestyle mobility is distinctive from the conventional foci of home-making that are associated with security and familiarity. Instead, the new Lijiang residents are more empowered to seek a community which holds values that they identify with themselves, a place that they see as supplying them with the opportunity for personal advancement. However, lifestyle mobility is not a uniform and universal model; it is strongly influenced by external and structural factors such as, for instance, social class and ethnicity. In the case at hand, the individuals studied are urban middle class Chinese who at a particular stage of their lives felt motivated to search for both alternative lifestyles and new experiences of home-making so as to fulfil both their emotional and financial needs.

\section{Home, mobility and tourism in China}

The English term 'home' originated from the Anglo-Saxon word 'ham' which means village, estate or town (Hollander, 1991). In the late 17th century, the notion of home in Europe emerged from the division of public and private, the separation between household and society, and the rising individual need of intimacy, personal fulfilment and relaxation (Somerville, 1997). Traditionally, the notion of home often symbolises the idea of birth, family dwelling or a morality of protecting property (Mallett, 2004). Due to the dramatic changes of social forms in the West, the Protestant reformation, the cult of domesticity, industrialisation and the formation of modern state has all contributed to evolving notion of 'home' [Ebrey, (1990), p.199]. In modern western societies, it indicates the need of being stable, peaceful, authentic and safe (Ellingsen and Hidle, 2013).

In contrast, in ancient China, there was no proper Chinese word that fully refers to the English notion of 'home'. Due to the influence of Confucian ethics, ancestral rites, and the fundamental principle of patrilineality, there is a high level of standardisation of family practices across different regions and territories in China (Cohen, 1991). Since the unification of the country by the Qin Dynasty (221 BC-207 BC), the patrilineal clan (zong) has become the main unit of a society that categorises people with same surnames (xing), the same ancestor, land, property, and marriage practices. In Han traditional society, the patrilineal family (jia) has become the main enterprise of "consumption and production under the authority of a family head" [Ebrey, (1990), p.204].

As the foundation of Chinese civilisation, one of the key elements of Confucianism is 'filial piety' which means "obedience to and care and respect of family elders" [Jacka et al., (2013), p.27]. In his Analects, Confucius indicated that the private home is politically significant because "self-cultivation and governing a home is the root of social order and the basis for political stability and universal peace" (xiushen, qijia, zhiguo, pingtianxia). Under such norms, most Chinese people were encouraged to stay at their home village or town without too much travel and engagement with the outside world. ${ }^{4}$ 
Traditionally, family members were encouraged to live in one household, working and producing for the family as a whole. Although various forms of travel already existed since the Tang Dynasty (618-907), such activities were often limited to social elites or business merchants. They either travelled to the capital for imperial examination to become political officials, or occasionally travelled to the countryside to escape from the political control or to pursue spiritual self-nourishment (Salazar and Zhang, 2013). During the Tang and Song dynasties (618-1279), a number of literati, such as Li Bai and $\mathrm{Du} \mathrm{Fu}$, have written poems about their official or personal journeys of visiting temples or climbing on mountains with family and friends (Nyíri, 2006). As Oakes and Sutton (2010, p.11) argued, such forms of travel, mainly by scholar-officials and cultural celebrities, were associated with a certain form of civilised modernity, showing their moral superiority when compared to the mass of ordinary Chinese.

In 1951, after the founding of the People's Republic of China (PRC), the hukou Registration Regulation was established in cities and extended to the rural areas in 1955. This household registration system was inherited from ancient China to govern citizens' social welfare. ${ }^{5}$ According to the regulation, the hukou system divides nationals' personal status by two related indicators: residential location (hukou suozaidi) and socio-economic eligibility (rural or urban hukou) [Chan and Zhang, (1999), p.821]. The Chinese government has used such regulation as a tool to monitor internal migration so as to ensure social stability and economic growth. The system also allowed the state to regulate individuals' daily life and mobility. For instance, rural hukou holders cannot receive the same state social benefits as urban dwellers, including education, arranged employment and retirement benefits. Since 1980s, the nationally increased mobility, especially the emergence of the 'floating population', challenged the basis of the hukou system leading to various new reforms. The introduction of new measures, such as temporary residence certificate in big cities, has opened urban residency to rural people and relaxed some degree of control [Chan and Zhang, (1999), p.831].

From 1949 to 1978 , the state also changed its attitude towards other social activities of mobility such as tourism. In 1950s, tourism was only a form of special political activity to "enhance China's political influence and propagate the achievements of socialist reconstruction" - an activity organised for foreign diplomats with permission to visit China under strict surveillance (Sang, 2009; Sofield and Li, 1998). Self-funded domestic tourism hardly existed, and outbound travel was limited to diplomats and important government officials at public expense. During the Cultural Revolution (1966-1976), tourism was considered to be a reflection of a capitalist bourgeois lifestyle and was therefore largely shunned, although a number of Chinese youth (the Red Guards) frequently visited places with historical significance to Chinese Communism (a similar activity to the red tourism of nowadays). They travelled around the country to "exchange experience, destroy feudal sites, and visit sites of Red Army history" [Oakes and Sutton, (2010), p.11].

In July 1979, some months after China had initiated policies of economic reform, the Party leader Deng Xiaoping spent a three-day holiday at Yellow Mountain, a site which literati frequently visited in ancient China. During his stay, Deng encouraged transforming the tourism industry from a political activity to an economic enterprise (Sang, 2009). Following the policy changes as expressed by Deng's speech, at the first National Conference on Domestic Tourism in 1987, the Chinese government officially accepted tourism as an appropriate means to achieve political-ideological, socio-cultural and diplomatic objectives (Airey and Chong, 2011). Consequently, several policies were 
issued in the 1990s and 2000s to encourage Chinese to travel domestically as a means of stimulating consumption (Zhu, 2018). Policies include the development of thousands of heritage sites, scenic spots and theme parks, plus the establishment of a nationwide five-day working week (as opposed to the former six-day working week) in 1995 and of national holidays associated with traditional Chinese festivals. These changes create time away from work and thus make tourism activities possible.

The economic reforms in China of the 1980s and 1990s also led to various new forms of mobility, such as rural family tourism (Chio, 2014), seasonal lifestyle travel (Salazar and Zhang, 2013) and temporary relocation for education in prestigious universities in the coastal cities (Golley and Kong, 2013). The building of cross-regional transportation infrastructure in the past decade such as national highways, high-speed trains and low-cost airlines has resulted in a noticeable increase in domestic travel. According to statistics from the national Bureau of Statistics, China had 644 million domestic tourists in 1997; the number increases to 4,400 million in 2016. In the first decade or so of the 21 st century, central government has developed various polices, such as the new National Urbanisation Plan in 2014, so as to encourage the expansion of urbanisation and the rural-urban migration to increase the previously curtailed mobility of Chinese citizens. Moreover, and due to the loosening restriction of hukou registration regulation since 1980s, migrant labourers from rural areas are enticed to work in the cities through a temporary work permit, that allows them to equally access urban welfare in certain cities (Zhao, 1999). All of these new practices of mobility have become one of the critical components of the cultural changes that took place in Chinese modern society in late 20th and early 21 st centuries (Zhu et al., 2017).

The emergence of these new practices of mobility reflects the transformations of Chinese attitude towards 'home' in the recent decades. Along with the economic reform and increased urbanisation, the notion of home has shifted its traditional association from a lineage-bounded unit that aims at social stability to an individual enterprise that seeks to achieve personal happiness and success. Such shift is deeply embedded in the decreasing influence of Confucian ethics and the emergent consciousness of individuals in modern China, a change referred to what anthropologist Yan (2010) framed as a process of individualisation, in which Chinese individuals, especially the urban middle class, have the awareness and capacity to choose their own life path and forge an individual entity. It is argued then, that today, Chinese society offers its citizens many choices and channels through which they can pursue personal happiness and their dream of modernity. ${ }^{6}$

Nowadays, although 'filial piety' still continues to be practiced in many regions of the country, especially in rural areas, there is a rise of the private family which allows individual women and men to oppose the existing traditional norms and pursue their own individual life path. In contrast to well-known rural-urban migration that aimed at obtaining better social welfare, these new practices allow the urban middle class to travel or reside in the rural areas to pursue their imagined ideal lifestyle away from the cities. As in the case of the artists and educators who moved their family from Beijing to Yi County in Anhui province to open a café and an Avant-Garde bookshop (Krischer, 2015), the urban middle class individuals who are part of this study have developed ideas about their living environment in the countryside. Similar to the emerging form of lifestyle migration in northern America and Europe studied by Benson and O'Reilly (2016) and Fleischer (2007), these individuals yearn for a place to reside with greener spaces, better air quality and privacy. They often reject the label 'tourists' (youke), having the social 
and economic capital to choose places for work and living (Bourdieu, 1984). Similar to Su's (2014) observation, the new residents' conception of home in Lijiang is now strongly associated with the discovery of the self and comfort. Different from the earlier periods' pursuit of social stability and security, the new forms of mobility allow these middle-class Chinese to develop multiple homes that work toward their own individual life and personal happiness.

\section{Tourism development and lifestyle mobility in Lijiang}

Lijiang is located in Yunnan province in southwest China, neighbouring Laos, Myanmar, and Vietnam. It is a prefecture-level city, located 600 kilometres from the provincial capital, Kunming. ${ }^{7}$ Due to the significance of its geographical location for military and trade reasons, the area was once called China's 'Southgate', i.e., the route to Southeast Asia. Lijiang is populated by Naxi (also phrased as Nakhi), an ethnic group living in the borderlands between the Chinese and Tibetan areas. ${ }^{8}$ According to the 2010 census (Lijiang Bureau of Statistics, 2010), over $40 \%$ of Lijiang's population is Han Chinese, followed by $20 \%$ Naxi, while the remaining are made up of various other minorities, such as Yi, Lisu, Bai, Pumi, and Tai.

Lijiang has long been the political, economic and cultural centre of the Naxi and other minorities (Zong, 2006). In Naxi language, the town was originally called gongbenzhi meaning 'market and storage for rice'. Beginning in the 12th century, the town became a trade centre and commercial market, establishing advanced leather, textile, copper and iron industries. At the peak of its commercial development in the 13th century, the town accommodated an estimated 100 companies and 1,200 shops from different industries.

With the implementation of the open-door policy and economic reforms introduced by the post-Mao leadership in 1978, Lijiang has been among the earliest towns to promote heritage industry and ethnic tourism in China (Zong, 2006). Since then, the place has become a Mecca for foreign backpackers and increasingly, since the 1990s, for domestic tourists as well (Rees, 2000). Visitors were attracted by its picturesque landscape, narrow waterways, cobblestones streets, old houses, exotic religion, and most importantly, by the mythology of an exotic and isolated land promoted by its earliest Western visitors, amplified on the pages of guidebooks like Lonely Planet [Su and Teo, (2009), p.81].

The construction of modern transport infrastructures (an airport in 1995, railway in 2009 and the highway to the provincial capital in 2013) has brought a continuous rise in ethnic tourism in and around Lijiang. According to statistics from the Lijiang Bureau of Statistics, the town had 1.06 million domestic and 45,930 international tourists in 1996; increasing to 34.04 million Chinese and some 1.15 million international tourists in 2016. These numbers show that domestic tourism constitutes the majority of the tourist market. Domestic tourists also spend considerable amounts of money: in 1996 they spent 160 million yuan, a figure, which rose to a staggering 57.889 billion in 2016 (Lijiang Bureau of Statistics, 2017). ${ }^{9}$

Since the 1997 UNESCO listing of Lijiang as a World Heritage Site, a growing tourism industry has accreted the town's cultural contact with other parts of China, and with the globalised world. In this process, Lijiang went through a large-scale re-construction of traditional-style guesthouses, cultural theme parks and museums (Zhu, 2016). The image of the town, coined as a mysterious and exotic place in the imagination 
of Western backpackers through the legacy of early explorers, has been gradually transformed into a popular Chinese holiday destination, where people travel to in search of romance and alternative lifestyles (Zhu, 2012). Consequently, religious customs, ethnic music, festivals and handicrafts have all become tourist-orientated products so as to contribute to the development of ethnic tourism and stimulate the regional economy (Morais et al., 2006). In addition and parallel to the dramatically increasing numbers of tourists in Lijiang, there is a steady development of business investment. People from Zhejiang, Fujian, Sichuan and Guangdong provinces have gradually moved to Lijiang. The town subsequently became a playground for people who do not only search for the experience of more personal freedom, comfort and exoticism (Wang, 2007), but also for new business opportunities and alternative forms of lifestyle.

In tourism literature, such practices of relocation have often been regarded as 'second home tourism', a routinised movement from urban to rural areas that is associated with a desire to satisfy lifestyle choices and leisure (Dingsdale, 1986; Hall and Müller, 2004). To date, a number of similar practices have emerged in North America and Europe, such as lifestyle migration (Benson and O'Reilly, 2009), seasonal suburbanisation (Clout, 1974), multiple dwelling (McIntyre et al., 2006) or residential tourism (Casado-Diaz, 1999). Most scholarly literature, such as the one on lifestyle migration and second home tourism, is associated with identity expression and the way people wish to live their lives (Coles and Timothy, 2004): by moving to rural regions (part-time or full-time), they make use of their economic and cultural capital to manifest their prestigious status in the new locality (Kordel and Pohle, 2018).

However, as shown in Table 1, the binary categories often indicate a division between leisure and work: the principle home as 'work-oriented' and the tourism-destination home as 'leisure oriented' [Jaakson, (1986), p.376]. However, such binary division neglects the possibilities of reconsidering both changes of lifestyle and employment opportunities as one unit [McIntyre, (2013), p.196, cited in Benson and Osbaldiston, (2016), p.419]. To these emergent entrepreneurs who have relocated to Lijiang, their practices are not solely consumption of the 'exotic' countryside: local tourism industry also offers these urban middle class individuals an alternative business opportunity after their re-dwelling. In this sense, although the notion of 'expatriate tourism' might fit better with the multi-functional nature of such mobility, it fails to show people's strong intention of re-dwelling and home-making as observed by myself in Lijiang. As most of my informants said, "this is my new home. I am a new Lijiang resident (xin Lijiang ren)."

Table 1 Difference between second home tourism and lifestyle mobility in China

\begin{tabular}{lcc}
\hline & Main home & Second home \\
\hline Second home tourism & Work & Leisure \\
Lifestyle mobility & Social welfare $($ hukou $)$ & Work and leisure \\
\hline
\end{tabular}

As stated earlier, in this paper, instead of creating a new typology between tourism and migration, I echo Cohen et al.'s (2013) notion of 'lifestyle mobility' to describe such phenomena that reflects the multi-functional and fluid nature of these movements. Lifestyle mobility allows 'ongoing semi-permanent movement of varying durations', 'multiple mooring' that 'may involve return to homes', with 'varying duration of stay', and 'multi-transitional' sojourns with 'some seasonal variation' that might be 'ongoing throughout the life-course' [Cohen et al., (2013), p.4; cited from Benson and Osbaldiston, 
(2016), p.417]. Different from 'lifestyle migration', the concept of lifestyle mobility opens the possibilities of other flows such as of capitals, information, knowledge and skills. It also shows the process of how people "manage movement, harness technology, and develop social networks to realise their projects and plans while being on the move" [McIntyre, (2013), p.96].

\section{From tourism to relocation}

The lifestyle mobility of urban Chinese analysed in the paper is intrinsically tied to tourism. As a popular destination, the historic town of Lijiang hosts tourists largely from the more economically developed east. Lijiang, as Su (2014) notes, functions as a reflection of visitors' personal romanticisation of the exotic. It is a place that attracts mostly Han urban Chinese searching for a spiritual home to cope with the pressures of fast-paced city lifestyles and the various environmental, dietary and psychological problems that come with such urban living. Whatever the motivating desires of visitors to Lijiang, many express a common experience of healing through their varying levels of engagement with the place and its region.

It is possible to identify different, but potentially overlapping, types of interactions with Lijiang by people coming from urban centres. Many of them feel offended if they are treated as tourists (youke): they prefer to call themselves travellers (luxingzhe). These travellers consider themselves engaged in more meaningful journeys, in opposition to tourists who simply consume transitory experiences in larger groups, transporting much of the fast-paced, overcrowded urban modes of living into the countryside. Travellers avoid popular tourist districts and seek a natural and peaceful place to live for several months. The typical traveller's day is unrushed and largely free of the urgencies of shortterm tourism and urban life. They wander about meeting friends, spend time on the Internet sharing photos, write dairies and have the freedom to simply enjoy the sunshine and their ideally imagined country life. More affluent travellers take long holidays with little financial burden while others are college students who have to work part-time in guesthouses to support their stay.

A few months after their initial arrival, some travellers decide to become new residents in the town. They often rent houses in the old town and some go as far as buying apartments in the new part of Lijiang. Mr. Zheng, a 38-year-old traveller turned new resident, left his job at a well-known state enterprise in Beijing to settle in Lijiang's old town. His first visit to the area was in 2003 and he remembers being impressed by the natural beauty and exotic culture of the place. After returning to Lijiang numerous times, he relocated and settled in the town in 2008 .

Mr. Zheng describes his relocation as an escape from the tedium and stress of city life and Chinese bureaucracy. He shops at local markets, eats and drinks tea with friends and enjoys a less pressured daily schedule. He participates in volunteer organisations made up of fellow travellers with similar backgrounds and motivations. These activities help him build up a sense of belonging in his new chosen home. These social networks of exclusively new Lijiang residents also allow him to participate in events and cultural activities, and it was through these events that he met his partner in 2011.

For many new residents, Lijiang is not only a place of indulgence, freedom, pleasure and recreation, but also a place where they can develop a feeling of community that shares similar symbolic forms, morals, values and language. Unlike in their previous 
urban homes, new residents feel such community building is crucial at this stage of their life, enabling them to be recognised and valued by groups of like-minded people. For them, Lijiang functions as their new home, a place that is more authentic, purer and simpler than the places they come from. However, most of them show no interest in the history of Lijiang; they do not engage with the local Naxi community or the specificities that might exist beyond their imagination of the place as an idyllic escape.

\section{From relocation to entrepreneurship}

Unlike the majority of cases located in other countries and discussed in the second home literature, Lijiang does not serve just as a place to obtain a better lifestyle. Many travellers to Lijiang bring with them significant cultural and economic capital which they use to start new businesses in the local tourism industry [Zhu, (2018), p.114]. These businesses provide new residents with the means to make a considerable break from the conventional urban careers in which they felt trapped. Typically, new residents start guesthouses, hostels, souvenir shops or other small businesses in the old town, using their middle class status and professional experience to establish business connections with the local government.

Wang and Yan are examples of urban professionals who followed this path from travellers to new residents and became tourism entrepreneurs in Lijiang. Wang, a 36-year-old manager from a four-star international hotel in Shanghai travelled around the country with his sister Ling in 2008. Along their journey, they decided to settle in Lijiang and, with the support of friends, opened a high-end luxury hotel there called the Blossom Hill Inn (huajiantang). Wang and his sister's new lifestyle in Lijiang are typical of new residents in the town. They treat self-employment as an essential part of their search for a new lifestyle with a greater balance between work and leisure.

In 2009, Wang met Yan at his hotel when Yan travelled around the region as a tourist. Six months later, Yan decided to quit her job at an international training company in Chongqing and moved to Lijiang. They married two years later at a place in Lijiang where traditional Naxi weddings are performed for tourists. For the couple, their Naxi-style wedding was not simply an exotic tourism activity, but an important moment to celebrate their independence and strengthen their sense of belonging to their chosen home. With their friends as witnesses, their wedding was both a celebration of their marriage and a powerful assertion of their self-determination (Zhu, 2018). Wang and Yan's move to Lijiang was part of a search for a new lifestyle and home, born out of an emotional dissatisfaction with city living and the constraints of traditional family and kinship ties. The couple developed in Lijiang a sense of home centred on a spiritual connection between a small group of people sharing the same desires ( $\mathrm{Su}, 2014)$.

After their wedding, Wang and Yan used their professional experience to turn the Blossom Hill Inn into a chain of hotels and opened eight guesthouses in the town. As Yan pointed out, they hire a number of people from other cities. Each of their hotels has a manager originating from outside of Lijiang, with several Naxi employees who assist with management and cleaning. Additionally, and building on the recent promotion of 'old towns' for heritage tourism development in China, the couple opened businesses in Shangri-La in Yunnan, Wuzhen in Zhejiang, and Langzhong in Sichuan. Their businesses model has been to redesign traditional courtyards houses into opulent guesthouses aimed 
at the high-end tourism segment, both for domestic and international visitors. By combining modern and traditional aesthetics to repackage Lijiang's Naxi heritage as a familiar exotic tourist product, they have created a successful tourist package that satisfies the desires and expectations of heritage tourists.

By becoming new residents in Lijiang, these urban expatriates gain access to lives and new business ventures that open a space for 'opportunity and hope' [Hage, (1997), p.3]. The guesthouses they stay in and run as businesses do not simply serve as places to inhabit, but also feed their emotional and material needs for personal growth. New residents are able to build such successful businesses because they exploit their greater skills in business management to compete against local Naxi entrepreneurs. With the support of local government, new residents' social and cultural capital offers them a friendly business environment which they can use as a platform to gain a voice in local affairs.

\section{A new home apart, disenchantment and return}

Lijiang offers a place where people reinforce their fantasy of a rural life seemingly free of urban chaos and stress while retaining the social and economic benefits of their previous homes [Zhu, (2018), p.129-136]. This new lifestyle hinges on a fragile balance between new residents' production of a simpler, more spiritual home and the need to indulge in the leisure comforts of urban affluence. Commercial tourism in Lijiang is one of the major threats to this precariously fabricated life-balance. Some, like Mr. Zheng, lament the loss of a Lijiang they associate with their early years of travelling. Others, such as Wang and Yan, focus on complaints following from the development of mass tourism, like the noise at night along the bar street, the increase in traffic congestion and living cost, and the inconveniences of shopping and living in the old town (Su, 2014). Over time these concerns erode their romantic fantasies about Lijiang's heritage and their new lives there.

In order to maintain their ideal life, new residents distance themselves from many of the exotic aspects of the place. Instead of engaging with a life in line with the native community and Naxi culture, new residents retain much of their behaviour and routines from their previous lives. They eat in modern restaurants, drink imported wine, lounge in cafés reading books, spend time at home playing with their pets and regularly pay for massages. Even though some new residents have lived in Lijiang for over a decade, they continue to distance themselves from local residents, retreating into the comforts of affluent urban life. This retreat allows new residents to safely consume the exotic under their own terms while transplanting the desirable aspects of their city lives into their new sense of an ideal rural home.

In the past decade, Lijiang has undergone dramatic changes due to the heritage tourism developments in the region. Every day, local residents struggle with the floods of mass tourists which dispossess them from their own heritage. Consequently, they choose to leave their houses to outsiders and profit through rent [Su and Teo, (2009), pp.157-161]. The new residents experience a similar sense of 'being dispossessed' by mass tourism, and follow the footsteps of Naxi people and move out. Each day they go to the old town to work, allowing them to enjoy the traditional courtyard houses and exotic landscape. At night they return to the new town where they can retreat into a similar urban environment as their original homes. Different from native residents, they are able 
to move between the new and old areas of Lijiang, a form of daily lifestyle mobility in the region.

New residents have another strategy for improving their quality of life, one not available to native residents. They retain their urban hukou (household registration) and move between rural Lijiang and their home cities to take advantage of better welfare. Mr. Zheng, for instance, often returns to Beijing for medical treatment. Such freedom of movement allows them to opt in and out of the disadvantages of rural life.

In addition, retaining one's hukou also allows new residents greater choice for the education of their children. ${ }^{10}$ Since 2000 , new tourism infrastructure has been built around the region, including a new airport, a train station and numerous luxury hotels. Yet there are only two colleges and local high schools in the region. New residents are left with little options for their children's schooling and they often decide to take their children back to their previous hometowns for a better education. By retaining their hukou, new residents are able to mitigate the risks and challenges that would otherwise accompany their new rural lifestyles. They move between new and old homes to take advantage of urban welfare and pension while consuming the joys of living in Lijiang, exercising a lifestyle mobility that is not open to locals.

Not all new residents are able to accord their sense of paradise with the pressures and disillusionment of their everyday lives in Lijiang. Talking to Yan in 2016, I heard that Wang and Yan were living in Chongqing for most of the year, so their five-year old daughter could have a better education and Yan could develop her business by managing a children's bookstore. As they encountered more of the reality of Lijiang outside their insulated new lifestyle, they distanced themselves from their imagined ideal sense of home. Eventually they were unable to maintain the balance between Lijiang's real world and their utopia, a gap which led to their decision to depart.

As Wang and Yan's sense of home shifted, Lijiang became a place of nostalgia for the perfect life they temporarily enjoyed there. This place had offered them a new, alternative sense of home tied to their dream career paths, a dream that arose out of a response to a specific point in their lives. Once they became parents and entered a new stage of life, Lijiang no longer suited their needs; their desires and sense of home shifted. By returning to Chongqing, Wang and Yan realigned their lived reality with their shifting sense of home as it moved from the one based in idealised emotional needs to the one focused on more functional needs associated with education and health. Yet, this shift was not an absolute break; the couple often returns to Lijiang to take care of their business, temporarily evoking the old sense of home associated with their past life.

\section{Discussion}

Based on his ethnography in the Indian Ocean, Picard (2011) illustrates that tourism offers a magic effect that transforms destinations into magic pleasure gardens in which nature and culture are cultivated for consumption. In Lijiang, it is the magic of exoticness centred on the impetus of such lifestyle motility that drives the urban middle class to engage in new practices of home-making. The magic effect of tourism does not only fulfil people' needs of escape from fast-paced urban lifestyle, but also contributes to the individual pursuit of happiness and success in Chinese modern society. In the process of relocation and re-dwelling, they actively adapt, revise and re-design their new homes to 
fulfil various demands. Serving both purposes of comfort and capital accumulation, lifestyle motility allows people to consume an instantly satisfactory presence of a new home while using professional skills to pursue new entrepreneurship in local tourism industry. They engage with the new lifestyle and business in their own ways, thereby maintaining a distance between themselves and the 'lure of the exotic' that attracted them in the first place.

In the 21 st century, the traditional understanding of home, in connection with kin and family (such as filial piety in traditional Chinese society), are challenged by the increased high mobility in search of employment or opportunities for life-style improvement (Coles and Timothy, 2004). Described as hybridity, in betweenness and third space (Bhabha, 1994), modern society allows us to move around the world involving the 'lifestyle of regularity, repetition and cyclicity' [Seamon, (1985), p.227]. As Marschall (2017, p.4) presented in her edited book Tourism and Memories of Home, 'home' can be something familiar, safe, comfortable and deeply rooted from the past memory or the origin, but it can also refer to something strange, imagined, exotic, and places that people express freely about themselves.

In Lijiang, the emerging lifestyle mobility is less related to people's cultural roots - the geographical origin of where they come from. For people like Sang, Wang and Yan, they are not concerned about the questions of 'who I am' and 'where I come from'. Instead, they are more interested in 'what I am doing' and 'where I am going to'. Each stage of their past contributes to the current journey of home-making and future planning. While enjoying freedom, romance and an exotic atmosphere, they do not leave behind their materialistic, capitalistic and consumerist privileges. Working in the tourism industry allows them to stay in their comfort zone while their previous social and cultural capitalist ideals become important resources to sustain their dream. Instead of the close linkage with cultural roots, their perception of home rather focuses on 'routes', a continuous process of 'putting into action' or, more precisely, the acts of habitations [Casey, (2001), p.412].

In the meantime, lifestyle mobility is a step-by-step move in which initial tourism leads to temporary migration, new home and alternative business. Here home is less about a bounded place, a thing or a person, but rather about practices - the way people do and feel. Such process involves the acts of imagining, searching, creating, unmaking, changing, losing, and moving [Al-Ali and Koser, (2001), p.6]. Lifestyle mobility is also not a single act. Once the 'magical effect' of tourism fades away in Lijiang, their pleasure is replaced by a daily struggle with the local living environment. The gap between imagination and reality results in a process of coping and negotiation between old and new homes. With the departure for new rounds of searching and strategising, their home-making becomes an on-going cycle of linking the present to the past and the future.

Modern society allows people to keep searching for and creating multiple places where they feel at home. Being at home and being away are not necessarily two oppositional experiences (Ahmed, 1999). Moving from one place to another becomes an act of multiple home-making that relates to various demands. While some needs are functional and are associated with material goods and social welfare, others are emotional and are tied to intimacy, pleasure or comfort. While some divide the function of home between work and leisure, others such as these tourism entrepreneurs in Lijiang, embrace the emotional and functional needs together. Home is no longer here nor there; it becomes a mobile bond connecting oneself with multiple places simultaneously and throughout different life-stages. 
However, despite lifestyle mobility emphasising individual agencies, actions are closely influenced by certain external factors and structural conditions [Korpela, (2014), p.42]. Here I list three structural and material conditions that matter to the shifting perceptions of home: class, ethnicity and life stages.

Firstly, lifestyle mobility is a particular class issue. Only a few people in contemporary Chinese society have the awareness and ability to strategise, to choose and move for the purpose of a good life (Benson and Osbaldiston, 2016). The freedom and skills to control some aspects of life is a fundamental characteristic of the middle class (Savage, 2000; Skeggs, 2004). Just as Oliver and O'Reilly (2010, p.63) described in relation to the British migrants in Spain, "class is a material reality which structures the extent to which people can live in Spain, the manner in which they live and whether they can stay there." For the Chinese middle class from more economically powerful cities like Beijing, Shanghai and Shenzhen, their main concern, as part of the outcome of cities' complex and rapid transformation, are issues relating to air quality, the costs of living and food safety. Their pursuit of happiness is not only limited to external and material factors (such as money, housing and cars), but is also extended to lifestyle-centred, affective and emotional experiences. More importantly, their socio-cultural and economic capitals allow them to temporarily depart from their original homes, relocate and access a network of activities in various life domains (such as work, health, leisure and family) to fulfil both their material and emotional needs.

Secondly, lifestyle mobility in Lijiang is associated with Han Chinese consumption of national minority areas for hedonistic desire and instant gratification, phrased as 'romantic consumption' (Zhu, 2018). In post-Mao China, numerous published volumes and local gazetteers (difangzhi) on ethnic minorities written by Han anthropologists and officials establish 'an ethnocentric hierarchy' that supports state-guided interethnic integration [Davis, (2005), p.19]. Han Chinese are described as modern and civilised; ethnic people are presented as backward, feminine and exotic (Gladney, 1994; Diamond, 1988; Schein, 1997). Consequently, a self-other relationship between Han Chinese and minority groups are created to motivate people from economically advanced areas to seek the 'backward' and 'exotic' others within their own nation (Zhu et al., 2017). Visiting these ethnic minorities can be an act of curiosity or 'internal orientalism' (Schein, 1997), and an opportunity to develop business privilege in local tourism industry.

Thirdly, the conception of home also changes over the course of a life and in different spatial contexts. Judging from the stories of lifestyle mobility in Lijiang, these people are more interested in their emotional needs after they accumulate enough economic capital and social experience from their past. Home-making at this stage becomes experience-oriented, self-directed and can be creative and adventurous. People relocate due to the exotic landscape, the alternative lifestyle and the social networks facilitating caring, sharing and solidarity of feeling and action. However, when people like Wang and Yan enter a new stage of life (getting older or starting a family), their needs for home becomes more functional, domesticated, and often orientated by concerns of education, social welfare and other practical issues. This new phase of life requires enhanced comfort and familiarity as a way of acquiring continuity and stability of lived experience (Somerville, 1997). 


\section{Conclusions}

Providing a glimpse into the microcosm of Lijiang, this paper reflects a complex nature of home as an assemblage of imaginaries, tensions, and desires that co-exist, interact, and are negotiated consistently. The story of Lijiang resonates beyond China; it helps us to comprehend the shifting conception of home and our practices of daily life in an on-going process of movement and dwelling around the world. It approaches the question of how new meanings of mobility influence our identity-making, vision of life and sense of belonging as objectified in the lived idea of home. The desire of obtaining a better status in life and the dissatisfaction with reality leads to a never-ending journey of upward social mobility in various forms of accumulating socio-cultural and economic capital.

What is the power relation and economic disparities between migrants and the host community? How do people from other social classes, such as migrant workers or the homeless, experience this situation? What role does gender play in this home-making via mobility? All of these questions need to be further examined within the context of China's cultural-social and economic transformations that are embedded in the consistent interaction between the urban and the rural, the state and the individual, as well as tradition and modernity.

\section{Acknowledgements}

The author would like to acknowledge the generous support of the Australian National University and Australian Academy of the Humanities. Special thanks to Paula Mota Santos, Naomi Leite, Nelson Graburn, Xiaobo Su, Christina Maags, Ben Houghton and the two anonymous reviewers for their comments.

\section{References}

Ahmed, S. (1999) 'Home and away: narratives of migration and estrangement', International Journal of Cultural Studies, Vol. 2, No. 3, pp.329-347.

Airey, D. and Chong, K. (2011) Tourism in China: Policy and Development Since 1949, Routledge, London.

Al-Ali, N. and Koser, K. (2001) New Approaches to Migration? Transnational Communities and the Transformation of Home, Routledge, London, New York.

Benson, M. and O'Reilly K. (2009) 'Migration and the search for a better way of life: a critical exploration of lifestyle migration', The Sociological Review, Vol. 57, No. 4, pp.608-625.

Benson, M. and O'Reilly, K. (2016) 'From lifestyle migration to lifestyle in migration: categories, concepts and ways of thinking', Migration Studies, Vol. 4, No. 1, pp.20-37.

Benson, M. and Osbaldiston, N. (2014) Understanding Lifestyle Migration: Theoretical Approaches to Migration and the Quest for a Better Way of Life, Palgrave Macmillan, Houndmills, Basingstoke, Hampshire.

Benson, M. and Osbaldiston, N. (2016) 'Toward a critical sociology of lifestyle migration: reconceptualizing migration and the search for a better way of life', The Sociological Review, Vol. 64, No. 3, pp.407-423.

Bhabha, H.K. (1994) The Location of Culture, Routledge, New York, NY.

Bourdieu, P. (1984) Distinction: A Social Critique of the Judgment of Taste, Routledge \& Kegan Paul, London. 
Brubaker, R. and Cooper, F. (2000) 'Beyond 'identity', Theory and Society, Vol. 29, No. 1, pp.1-47.

Casado-Diaz, M.A. (1999) 'Socio-demographic impacts of residential tourism: a case study of Torrevieja, Spain', The International Journal of Tourism Research, Vol. 1, No. 4, pp.223-237.

Casey, E.S. (2001) 'Body, self and landscape: a geophilosophical inquiry into the place-world', in Adams, P.C., Hoelscher, S. and Till, K.E. (Eds.): Textures of Place: Exploring Humanist Geographies, pp.403-425, University of Minnesota Press, Minneapolis.

Chan, K.W. and Zhang, L. (1999) 'The hukou system and rural-urban migration in China: processes and changes', The China Quarterly, Vol. 160, pp.818-855.

Chio, J. (2014) A Landscape of Travel: The Work of Tourism in Rural Ethnic China, University of Washington Press, Seattle.

Clout, H.D. (1974) 'The growth of second-home ownership: an example of seasonal suburbanization', in Johnson, J.H. (Ed.): Suburban Growth: Geographical Processes at the Edge of the Western City, pp.101-127, John Wiley and Sons, London.

Cohen, M.L. (1991) 'Being Chinese: the peripheralization of traditional identity', Daedalus, Vol. 120, No. 2, pp.113-134.

Cohen, S., Duncan, T. and Thulemark, M. (2013) 'Introducing lifestyle mobilities', in Duncan, T., Cohen, S. and Thulemark, M. (Eds.): Lifestyle Mobilities: Intersections of Travel, Leisure and Migration, pp.1-20, Ashgate, Burlington, VT.

Coles, T. and Timothy, D.J. (2004) Tourism, Diasporas and Space, Routledge, London, New York, NY.

Davis, D. (2005) 'Urban consumer culture', The China Quarterly, No. 183, pp.692-709.

Després, C. (1991) 'The meaning of home: literature review and directions for future research and theoretical development', Journal of Architectural and Planning Research, Vol. 8, No. 2, pp.96-115.

Diamond, N. (1988) 'The Miao and poison: interactions on China's southwest frontier', Ethnology, Vol. 27, No. 1, pp.1-25.

Dingsdale, A. (1986) 'Ideology and leisure under socialism: the geography of second homes in Hungary’, Leisure Studies, Vol. 5, No. 1, pp.35-55.

Ebrey, P. (1990) 'Women, marriage, and the family in Chinese history', in Ropp, P. (Ed.): Heritage of China: Contemporary Perspectives on Chinese Civilization, pp.197-223, University of California Press, Berkeley.

Ellingsen, W.G. and Hidle, K. (2013) 'Performing home in mobility: second homes in Norway', Tourism Geographies, Vol. 15, No. 2, pp.250-267.

Feuerwerker, A. (1990) 'Chinese economic history in comparative perspective', in Ropp, P. (Ed.): Heritage of China: Contemporary Perspectives on Chinese Civilization, pp.224-241, University of California Press, Berkeley.

Fleischer, F. (2007) 'To choose a house means to choose a lifestyle, the consumption of housing and class-structuration in urban China', City \& Society, Vol. 19, No. 2, pp.287-311.

Gladney, D.C. (1994) 'Representing nationality in China: refiguring majority/minority identities', The Journal of Asian Studies, Vol. 53, No. 1, pp.92-123.

Golley, J. and Kong, S.T. (2013) 'Inequality in intergenerational mobility of education in China', China \& World Economy, Vol. 21, No. 2, pp.15-37.

Hage, G. (1997) 'At home in the entrails of the west: multiculturalism, ethnic food and migrant home-building', in Grace, H., Hage, G., Johnson, L., Langsworth, M. and Symonds, M. (Eds.): Home/World: Space, Community and Marginality in Sydney's West, pp.99-153, Pluto Press, London.

Hall, C.M. and Müller, D.K. (2004) Tourism, Mobility, and Second Homes: Between Elite Landscape and Common Ground, Channel View Publications, Clevedon.

Hesketh, T. and Ding, Q.J. (2005) 'Anxiety and depression in adolescents in urban and rural China', Psychological Reports, Vol. 9, No. 2, pp.435-444. 
Hollander, J. (1991) 'The idea of home: a kind of space', Social Research, Vol. 58, No. 1, pp.31-49.

Jaakson, R. (1986) 'Second-home domestic tourism', Annals of Tourism Research, Vol. 13, No. 3, pp.367-391.

Jacka, T., Kipnis, A.B. and Sargeson, S. (2013) Contemporary China: Society and Social Change, Cambridge University Press, Cambridge.

King, B.E. and Ari Gamage, M. (1994) 'Measuring the value of the ethnic connection: expatriate travelers from Australia to Sri Lanka', Journal of Travel Research, Vol. 33, No. 2, pp.46-50.

Kordel, S. and Pohle, P. (2018) 'International lifestyle migration in the Andes of Ecuador: how migrants from the USA perform privilege, import rurality and evaluate their impact on local community', Sociologia Ruralis, Vol. 58, No. 1, pp.126-146.

Korpela, M. (2014) 'Growing up cosmopolitan? Children of Western lifestyle migrants in Goa, India', COLLeGIUM: Studies across Disciplines in the Humanities and Social Sciences, Vol. 15, pp.90-115.

Krischer, O. (2015) 'A new cultural ecology?', in Davies, G. et al. (Eds.): Yearbook 2015: Pollution, pp.138-143, ANU Press, Canberra.

Lijiang Bureau of Statistics (2010) Lijiang Tongji Nianjian 2010 (Lijiang Statistical Yearbook 2010), Lijiang Bureau of Statistics, Lijiang.

Lijiang Bureau of Statistics (2017) Lijiang Tongji Nianjian 2017 (Lijiang Statistical Yearbook 2017), Lijiang Bureau of Statistics, Lijiang.

MacKinnon, R. (2008) 'Flatter world and thicker walls? Blogs, censorship and civic discourse in China', Public Choice, Vol. 134, Nos. 1/2, pp.31-46.

Mallett, S. (2004) 'Understanding home: a critical review of the literature', The Sociological Review, Vol. 52, No. 1, pp.62-89.

Marschall, S. (2017) Tourism and Memories of Home: Migrants, Displaced People, Exiles and Diasporic Communities, Channel View Publications, Bristol.

McIntyre, N. (2013) 'Mobilities, lifestyles and imagined worlds: exploring the terrain of lifestyle migration', in Duncan, T., Cohen, S. and Thulemark, M. (Eds.): Lifestyle Mobilities: Intersections of Travel, Leisure and Migration, pp.193-208, Ashgate, Burlington, VT.

McIntyre, N., Williams, D. and McHugh, K. (2006) Multiple Dwelling and Tourism: Negotiating Place, Home and Identity, CABI, Wallingford, Oxforshire, UK, Cambridge, MA.

Morais, D.B., Dong, E. and Yang, G. (2006) 'The ethnic tourism expansion cycle: the case of Yunnan province, China', Asia Pacific Journal of Tourism Research, Vol. 11, No. 2, pp.189-204.

Nowicka, M. (2007) 'Mobile locations: construction of home in a group of mobile transnational professionals', Global Networks, Vol. 7, No. 1, pp.69-86.

Nyíri, P. (2006) Scenic Spots: Chinese Tourism, the State, and Cultural Authority, University of Washington Press, Seattle.

Oakes, T. and Sutton, D.S. (2010) Faiths on Display: Religion, Tourism, and the Chinese State, Rowman and Littlefield Publishers, Lanham.

Oliver, C. and O'Reilly, K. (2010) 'A Bourdieusian analysis of class and migration: Habitus and the individualizing process', Sociology, Vol. 44, No. 1, pp.49-66.

Picard, D. (2011) Tourism, Magic and Modernity: Cultivating the Human Garden, Berghahn Books, Oxford.

Ralph, D. and Staeheli, L.A. (2011) 'Home and migration: mobilities, belongings and identities', Geography Compass, Vol. 5, No. 7, pp.517-530.

Rees, H. (2000) Echoes of History: Naxi Music in Modern China, Oxford University Press, Oxford.

Rofel, L. (2007) Desiring China: Experiments in Neoliberalism, Sexuality, and Public Culture, Duke University Press, Durham. 
Salazar, N.B. and Zhang, Y. (2013) 'Seasonal lifestyle tourism: the case of Chinese elites', Annals of Tourism Research, Vol. 43, pp.81-99.

Salazar, N.B. and Zhu, Y. (2015) 'Heritage and tourism', in Meskell, L. (Ed.): Global Heritage: A Reader, pp.240-258, Wiley Blackwell, Chichester.

Sang, Y. (2009) '1979: Huang Shan, selling scenery to the bourgeoisie: an oral history account of Chinese tourism, 1949-1979', China Heritage Quarterly, Vol. 18 [online] $\mathrm{http} / / /$ www.chinaheritagequarterly.org/features.php?searchterm=018_1979huangshan.inc\&iss ue $=018$ (assessed 2 February 2018).

Savage, M. (2000) Class Analysis and Social Transformation, Open University, Buckingham, England, Philadelphia, PA.

Schein, L. (1997) 'Gender and internal orientalism in China', Modern China, Vol. 23, No. 1, pp.69-98.

Seamon, D. (1985) 'Reconciling old and new worlds: the dwelling - journey relationship as portrayed in Vilhelm Moberg's 'emigrant' novels', in Seamon, D. and Mugerauer, R. (Eds.): Dwelling, Place and Environment: Towards a Phenomenology of Person and World, pp.227-245, Springer, Dordrecht.

Skeggs, B. (2004) 'Context and background: Pierre Bourdieu's analysis of class, gender and sexuality', The Sociological Review, Vol. 52, No. 2, pp.19-33.

Sofield, T.H. and Li, F.M.S. (1998) 'Tourism development and cultural policies in China', Annals of Tourism Research, Vol. 25, No. 2, pp.362-392.

Somerville, P. (1997) 'The social construction of home', Journal of Architectural and Planning Research, Vol. 14, No. 3, pp.226-245.

$\mathrm{Su}, \mathrm{X}$. (2014) 'Tourism, modernity and the consumption of home in China', Transactions of the Institute of British Geographers, Vol. 39, No. 1, pp.50-61.

$\mathrm{Su}, \mathrm{X}$. and Teo, P. (2009) The Politics of Heritage Tourism in China: A View from Lijiang, Routledge, London/New York.

Wang, Y. (2007) 'Customized authenticity begins at home', Annals of Tourism Research, Vol. 34, No. 3, pp.789-804.

$\mathrm{Xu}, \mathrm{H}$. and $\mathrm{Wu}, \mathrm{Y}$. (2016) 'Lifestyle mobility in China: context, perspective and prospects', Mobilities, Vol. 11, No. 4, pp.509-520.

Yan, Y. (2010) 'The Chinese path to individualization', The British Journal of Sociology, Vol. 61, No. 3, pp.489-512.

Yau, N. (2007) 'Celtic Tiger, hidden dragon: exploring identity among second generation Chinese in Ireland', Translocations, Vol. 2, No. 1, pp.48-69.

Zhang, L. and Ong, A. (2008) Privatizing China: Socialism from Afar, Cornell University Press, Ithaca.

Zhao, Y. (1999) 'Labor migration and earnings differences: the case of rural China', Economic Development and Cultural Change, Vol. 47, No. 4, pp.767-782.

Zhu, Y., Jin, L. and Graburn, N. (2017) 'Domesticating tourism anthropology in China', American Anthropologist, Vol. 119, No. 4, pp.730-735.

Zhu, Y. (2012) 'Shifting tourism images: the world heritage site Lijiang, China', Heidelberg Papers in South Asian and Comparative Politics, Vol. 67, pp.58-68.

Zhu, Y. (2016) 'Heritage making of Lijiang: governance, reconstruction and local Naxi life', in Brumann C. and Berliner, D. (Eds.): World Heritage on the Ground, Ethnographic Perspectives, pp.78-96, Berghahn, Oxford.

Zhu, Y. (2018) Heritage and Romantic Consumption in China, Amsterdam University Press, Amsterdam.

Zong, X. (2006) 'Tourism development and cultural change: a case study of Yunnan Province', Lijiang County Naxi Culture, China Tourism Press, Beijing. 


\section{Notes}

1 All the names appearing in this article are pseudonyms.

2 For instance, in urban China young Chinese practice family rituals more infrequently, which offers less opportunities to reinforce social ties with older family members and ancestors.

3 This study is based on an ethnographic account of new Lijiang residents who moved there from other cities. I conducted over 17 months of ethnographic fieldwork (May-November 2006, July-December 2010 and June-September 2011) in this town. To better grasp these subjects' living experience, I also traced the daily life (namely the activities in the guesthouses, restaurants, teahouses, bars, markets, and souvenir shops) of several married couples on each of my return visits to Lijiang from 2007-2011. Such a long-term observation allowed me to understand people's attitudes towards home and their motivation and experience of relocation.

4 Population movements did exist in different historical times of China due to the rapid growth of population especially in regions were commercial trade was paramount, such as the migration of 'overseas Chinese' from coastal provinces to Southeast Asia in Ming and Ch'ing dynasties, and the major migrations from northeast China to Manchuria in Ch'ing Dynasty [Feuerwerker, (1990), p.233].

5 This system, used to be called ' $h u j i$ ', originated from the ancient family register and has been practiced in many Asian countries including Japan, Korea and Vietnam.

6 The privatisation of business online media (Zhang and Ong, 2008; MacKinnon, 2008), social liberalisation, and wider tolerance of sexual love between unmarried partners (Rofel, 2007) have all also contributed to this trend.

7 Due to the People's Republic of China's large population and area, its administrative divisions consist of five levels: the province, prefecture, county, township, and village levels.

8 Naxi is one of 55 ethnic groups which have been classified by the Chinese government in 1950 s as part of the ethnic identification project to pursue social-cultural integration and geopolitical security. The ethnic people reside predominately in frontier lands of strategic significance, particularly in Yunnan, Tibet, Xinjiang and Inner Mongolia, constituting $60 \%$ of China's land.

9 International tourists contributed USD 9.7 million (ca. 80.6 million yuan) to Lijiang's earning in 1996. The figure increased to USD 484 million (ca. 3.08 billion yuan) in 2016 (Lijiang Bureau of Statistics, 2017), http://www.ljta.gov.cn/html/infor/tongjixinxi/14523.html.

10 In China, education options (especially high schools) are tied to social welfare and hukou. 